\title{
DUAS CABEÇAS, UMA SENTENÇA: MACHADO DE ASSIS, LIMA BARRETO E A CARACTERIZAÇÃO DA POLÍTICA BRASILEIRA EM ESAÚ E JACÓ E NUMA E A NINFA
}

\section{JÚLIO CEZAR BASTONI DA SILVA}

Universidade Estadual Paulista

Araraquara, São Paulo, Brasil

Resumo: À parte as diferenças que saltam aos olhos entre Machado de Assis e Lima Barreto, a representação da história brasileira constitui um tema sobre o qual ambos se debruçaram. Em Esaú e Jacó (1904), de Machado de Assis, e Numa e a Ninfa (1915), de Lima Barreto, a caracterização das questões políticas locais, ainda que por meio de processos narrativos diversos, parece se dar de maneira coincidente, sugerindo uma continuidade entre a estrutura sociopolítica do Segundo Reinado e a da República. Neste artigo, são analisadas as diferentes articulações formais dos romances que, não obstante sua singularidade, indicam a permanência de certos traços estruturais da sociedade brasileira, tais como o patrimonialismo, a dissociação entre sociedade e Estado, entre outros.

Palavras-chave: Esaú e Jacó; Numa e a Ninfa; Machado de Assis; Lima Barreto; processo político brasileiro.

\section{TWO MEN, ONE MIND: MACHADO DE ASSIS, LIMA BARRETO AND THE CHARACTERIZATION OF BRAZILIAN POLITICS IN ESAÚ E JACÓ AND NUMA E A NINFA}

Abstract: Despite the evident differences between Machado de Assis and Lima Barreto, the portrayal of Brazilian history constitutes a topic upon which both worked. In Esaú e Jacó (1904), by Machado de Assis, and Numa e a Ninfa (1915), by Lima Barreto, even using different narrative processes, the characterization of Brazilian politics is coincident, suggesting a continuity between the sociopolitical structure of the Imperial and Republican periods. This paper studies the different formal construction of both novels, which nevertheless indicate the permanence 
of certain structural features of Brazilian society, such as patrimonialism and the dissociation of State and society, among others.

Keywords: Esaú e Jacó; Numa e a Ninfa; Machado de Assis; Lima Barreto; Brazilian political process.

$\mathrm{M}$ uita tinta já correu sobre as diferenças e semelhanças entre Machado de Assis e Lima Barreto. Logo na recepção crítica das obras de Lima, nas primeiras décadas do século XX, a comparação parecia inevitável, o que inclusive levou a protestos do autor de Policarpo Quaresma, que via Machado como uma figura avessa a seu espírito criador. ${ }^{1}$ De fato, a figura de proa que Machado, desaparecido havia pouco, representava na prosa literária brasileira do período, avalizava a comparação com o escritor neófito que publicou seu primeiro romance um ano após a morte daquele, Recordações do escrivão Isaías Caminha (1909). Entre a obra de ambos, porém, há pontos de contato que certamente merecem ser explorados. Um deles seria a caracterização coincidente da política brasileira, menos em função de uma concomitância histórica que em termos de uma semelhança estrutural da prática social, impressa na literatura. Se Machado representara, em seus últimos romances, a crise do Segundo Reinado e os primórdios da República, instaurada em 1889, Lima Barreto tematizou as contradições do período republicano brasileiro a partir de sua segunda década de vigência. No entanto, há certa coincidência na representação dos dilemas políticos do país, que pareciam permanecer os mesmos: uma política realizada à margem das necessidades da população, profundamente elitista e personalista, para a qual as diferenças de filiação ou lealdade partidária estavam subsumidas a considerações outras que não as de um programa político. Desse modo, embora as figurações sejam diversas, há uma semelhança para a qual a construção literária aponta, organizando da superfície do problema político a representação formal de suas estruturas, cujo diagnóstico sugere a impressão de uma permanência dos mesmos dilemas.

Entre Esaú e Jacó (1904), de Machado de Assis, e Numa e a Ninfa (1915), de Lima Barreto, mesmo que consideremos suas diferenças, sem

1 Ver, por exemplo, a carta de Lima Barreto dirigida a Austregésilo de Ataíde, na qual o felicita por têlo, em carta aberta, separado da influência de Machado de Assis. BARRETO, Correspondência, vol. 2, p. 256. 
dúvida primordiais, o sentido da representação das questões políticas brasileiras permanece semelhante, caracterizando impasses não resolvidos na transição entre o Império e a Primeira República. As dissimetrias entre os romances evocam as diferenças existentes entre os escritores: ${ }^{2}$ enquanto o problema da política é uma questão entre outras passíveis de exploração no romance machadiano - conforme as afinidades teóricas ou de interesse do crítico -, devido à sua elaboração marcadamente complexa e elíptica, no caso de Lima Barreto a centralidade daquele vem à tona, em forma de caricatura e de sátira. ${ }^{3}$ É certo que estes não são processos alheios à vasta produção de Machado de Assis, aparecendo inclusive a forma caricatural em algumas personagens de Esaú e Jacó; no entanto, esses modos de figuração são sobremaneira mais frequentes na obra de Lima Barreto, para a qual o tom de libelo que a caracteriza se ajusta perfeitamente aos processos mencionados. ${ }^{4}$ Em Machado, a ironia em lugar da sátira, a aparente isenção mediada pelas intromissões do narrador, a forma do apólogo, do diálogo, entre outros processos utilizados em seus romances, contos e crônicas, formam uma constelação diversa, que contrasta com a denúncia quase sempre explícita dos narradores barretianos. É nesse sentido que John Gledson utiliza seu conceito de realismo enganoso para os romances machadianos, segundo o qual é necessário ler as constelações alegóricas dos romances para que a representação da sociedade do momento possa se revelar em sua complexidade. 5 Do mesmo modo, como comenta Gledson no tocante às crônicas da série $A$ Semana, publicadas na última década do século XIX, o aparente "tédio à controvérsia" - ${ }^{6}$ caracterização da personagem do conselheiro Aires em Esaú e Jacó, estendida por parte da crítica ao próprio

\footnotetext{
2 Sérgio Buarque de Holanda alude às diferenças entre os dois autores em seu prefácio ao romance Clara dos Anjos (1948), de Lima Barreto. Enquanto Machado de Assis seria caracterizado por maior contenção pessoal, refletida na literatura, a de Lima Barreto seria marcada por um veio confessional, que perpassa suas obras. Apesar de se referir à figura humana dos escritores, essas diferenças se fazem notar nas narrativas de ambos. Não é de se estranhar, pois, que Lima Barreto evitasse amiúde a comparação com Machado de Assis, recusando-lhe, aliás, o posto de maior prosador brasileiro. Ver: HOLANDA, Livro dos prefácios, p. 387. Ver também: CANDIDO, Os olhos, a barca e o espelho, p. 4749.

3 PEREIRA, A máscara do Dr. Bogóloff, p. 52-53.

4 PRADO, Lima Barreto: o crítico e a crise, p. 21.

5 GLEDSON, Machado de Assis: ficção e história, p. 23-25.

6 ASSIS, Obra completa, vol. 1, p. 965.
} 
narrador machadiano - seria "menos uma fuga à política do que um comentário sobre a política da República".?

Mesmo que se valham de processos no mais das vezes diversos, pois, a questão política brasileira permaneceria como foco da representação nos dois narradores, e a coincidência nessa caracterização sugere certa permanência estrutural de práticas e formas de vida social neste período entre a crise do Segundo Reinado e os primeiros anos da República. Por meio dos processos de composição diferentes, nesse sentido, há uma identidade de fundo no diagnóstico da estrutura política brasileira, representando problemas que seriam repostos posteriormente pelo pensamento social brasileiro - em obras como Raízes do Brasil (1936), de Sérgio Buarque de Holanda, Evolução política do Brasil (1933), de Caio Prado Júnior, entre outras -, tais quais o divórcio entre sociedade e Estado e o patrimonialismo, marcas já amplamente conhecidas da política local. Nesse sentido, nas sendas de uma relação entre a representação da sociedade e da política brasileiras nas obras dos dois autores, dois estudos avultam: Machado de Assis: a pirâmide e o trapézio (1974), de Raymundo Faoro, e Por que Lima Barreto (1981), de Paula Beiguelman. Embora diversos, já que o estudo de Faoro supera em extensão temática e interpretativa o estudo mais restrito de Beiguelman, ambos apontam para as questões sociais e políticas presentes na obra dos dois autores: enquanto Faoro se detém em problemas de ordem geral, que vasculha e expõe a partir de trechos da vasta obra de Machado, Beiguelman parte de Numa e a Ninfa e das narrativas curtas das Aventuras do Dr. Bogóloff, reunidas postumamente no volume Os Bruzundangas (1956). São obras de valia para situar a obra dos escritores em seu contexto e a representação que sobre ele realizavam. No entanto, diversamente dessas obras, partiremos aqui de questões composicionais dos romances Esaú e Jacó e Numa e a Ninfa, tentando indicar, ao cabo, as diversas formas que se articulam para o diagnóstico coincidente da política brasileira.

\section{Narradores e personagens no teatro da política brasileira}

Esaú e Jacó e Numa e a Ninfa são romances tão diversos do ponto de vista formal que, à primeira vista, se poderia recusar entre eles qualquer identidade na representação da política brasileira. No entanto, os processos diversos realizados nos romances são como meios específicos para dar a conhecer a realidade social do período, sem dúvida convulsivo e de incerta

7 GLEDSON, Introdução, p. 31. 
sorte: a crise do Segundo Reinado e os primeiros anos da República, marcados por crises políticas e insurreições de diversas ordens, no caso de Esaú e Jacó; e a política republicana que mantém certas práticas que, desde a colônia, marcam a sociedade brasileira, como o voto de cabresto e o profundo elitismo e personalismo das classes políticas, no momento da crise de transição entre o governo do falecido presidente Afonso Pena, assumido por Nilo Peçanha, e a candidatura de Hermes da Fonseca, em Numa e a Ninfa. À parte os diferentes índices temporais dos romances, interessa mais a caracterização estrutural dessa dinâmica histórica, para a qual os romances utilizam processos muito diversos e decerto característicos de ambos os autores.

Em Numa e a Ninfa, a estrutura de roman à clef é facilmente identificável. Esse processo, já utilizado em Recordações do Escrivão Isaías Caminha, coaduna com o tom de libelo do romance - algo correlato ao aspecto confessional das obras de Lima Barreto -, ao representar em certas figuras do romance personagens políticos de vulto da época, como o marechal Hermes da Fonseca na figura de Bentes, ou o senador Pinheiro Machado na de Bastos, entre outros do meio político e da imprensa do período. ${ }^{8}$ Publicado em folhetins no jornal $A$ Noite e divulgado com tintas sensacionalistas, ${ }^{9}$ em 1915 , tematiza os fatos políticos ocorridos havia poucos anos, já narrados em conto de mesmo nome que escrevera no calor da hora, em 1911, para as páginas da Gazeta da Tarde. ${ }^{10}$ Numa, protagonista do romance, é um deputado medíocre, cujos sucessos na política se dão com seu especial talento de farejar "onde estava o vencedor", ${ }^{11}$ isto é, à custa de relações pessoais com figuras de proa na política do momento, no caso, seu sogro, Neves Cogominho, presidente e chefe local do fictício Estado de Sepotuba. A "ninfa" é Edgarda, ambiciosa filha de Cogominho, que, evocando a narrativa clássica de Numa Pompílio, o político romano que receberia conselhos da ninfa Egéria, ${ }^{12}$ agencia a carreira política do marido, inclusive participando de suas articulações e da redação de seus discursos. A sátira, assim, apresenta-se na caricaturização centrada especialmente nos

\footnotetext{
$8 \mathrm{Na}$ biografia de Lima Barreto escrita por Francisco de Assis Barbosa é apresentada a "chave" do romance, ou seja, as figuras nele presentes que fazem referência direta a políticos e jornalistas do período. Ver BARBOSA, A vida de Lima Barreto, p. 192-193.

9 Idem, p. 232-235.

10 BARRETO, Contos completos de Lima Barreto, p. 689.

11 BARRETO, Prosa seleta, p. 420-421.

12 BEIGUELMAN, Por que Lima Barreto, p. 46.
} 
personagens políticos, sejam os que comandam a máquina do Estado, sejam os seus apaniguados e dependentes, como os capoeiras, os jornalistas delegados de interesses escusos e todo tipo de parasita das finanças públicas.

$O$ romance de Machado de Assis, por sua vez, tem configuração bastante diversa. A sátira aqui dá lugar a uma ironia que se quer distanciada, centrada na mediação que a personagem do conselheiro Aires traz à narrativa - o romance, segundo a "Advertência" que lhe serve de pórtico, teria sido baseado em um caderno do "Memorial" escrito pelo conselheiro, contendo seu diário e suas impressões gerais. ${ }^{13}$ Há, portanto, uma relação entre o narrador do romance, um narrador onisciente com caráter seletivo sobre as consciências dos personagens - com elipses e incursões significativas ao longo do romance - e a figura do conselheiro, tecendo considerações ora por sua própria conta, ora debitadas em nome de Aires; Alexandre Eulálio chama narrador e conselheiro, respectivamente, de "demiurgo-narrador" e "personagem-delegado", "o segundo incluído no primeiro, tendo um foco em comum". ${ }^{14}$ Assim, há certa identidade na postura entre cética e irônica de Aires no teatro do romance e o distanciamento com idas e vindas do narrador, que se recusam, ao longo da narrativa, a fixar juízos definitivos sobre as personagens do romance, em um jogo mútuo no qual o demiurgo-narrador ora oferece, ora retira a voz de Aires segundo sua própria veleidade. Desse modo, o romance se articula em dois âmbitos, aparentemente distintos, mas na verdade complementares: de um lado, a datação precisa de acontecimentos históricos e referências da passagem entre o Segundo Reinado e a República, inclusive com a menção a figuras reais do período; ${ }^{15}$ de outro, a relação simbólica - em figura de espelho - que envolve personagens, narrador e leitor virtual, ${ }^{16}$ assim como os ao mesmo tempo inconciliáveis e idênticos gêmeos Pedro e Paulo, a "inexplicável"17 Flora que oscila entre ambos, a sucessão de episódios significantes e um

13 ASSIS, cit., vol. 1, p. 946.

14 EULÁLIO, Esaú e Jacó: narrador e personagens diante do espelho, p. 130.

15 John Gledson chama a atenção a essa particularidade: "De fato, se nos outros romances é preciso buscar e interpretar, para encontrar e entender os significados políticos e históricos do livro, aqui, os acontecimentos, símbolos, nome alegóricos etc., que se relacionam com a política são tão numerosos a ponto de se tornarem inescapáveis". GLEDSON, Machado de Assis: ficção e história, p. 194.

16 EULÁLIO, cit., p. 123. Ver também GUIMARÃES, Esaú e Jacó e o leitor como duplo, p. 240.

17 ASSIS, cit., p. 986, 989, 1024. 
sistema de sucessão de "apólogos", como o chama Alexandre Eulálio. ${ }^{18}$ A dubiedade e o distanciamento seletivo, pois, dão o tom do romance, que em muito difere, nesse sentido, de uma crítica direta como a manifestada em Numa e a Ninfa.

A narração de ambos os romances, como se vê, é bastante diversa. Ao jogo formal mais elaborado do romance de Machado de Assis, contrasta Numa e a Ninfa o teor acusatório, por meio do qual o narrador desenha as figuras e monta os cenários dos diálogos e das ações, em uma espécie de posição que, no entanto, mal pode esconder a figura do intelectual avesso à política do momento. Como afirma Antonio Arnoni Prado, "a preocupação é muito mais fazer da literatura um meio de atuação social e política do que meramente situá-la como oposição aos modelos 'cerebrais e artificiais' consagrados"; ${ }^{19}$ nada mais oposto, portanto, ao tom geral de Esaú e Jacó, cujo teor crítico advém por procedimentos diversos. No romance machadiano, a história de Pedro e Paulo, gêmeos em tudo opostos, porém idênticos, as avaliações sibilinas do conselheiro Aires e as figurações alegóricas da política brasileira do momento são elementos que tomam a frente, envolvendo a representação da situação política em um registro de identidade e de permanência estrutural. Em Numa e a Ninfa, ao contrário, as avaliações do narrador vêm por meio das peripécias farsescas desempenhadas pelos personagens caricaturizados, e também pelas impressões e pensamentos dos personagens, como Benevenuto e Bogóloff, o que faz com que o narrador pouco precise opinar por meio de discurso direto.

Esse duplo procedimento entre a narração e as figuras do romance que funcionam - falando com o conceito de Alexandre Eulálio - como "delegados" do narrador pode ser exemplificado na comparação direta entre as narrativas. No capítulo "O basto e a espadilha", de Esaú e Jacó, ambientado na noite de 15 de novembro - dia da proclamação da República -, o banqueiro Santos encontra-se em sua casa, com amigos, para o voltarete de costume. Santos, tocado pelos acontecimentos recentes, quis evitar o

18 EULÁLIO, cit., p. 115. Segundo o crítico, haveria uma sucessão de "unidades apologais" no romance, que funcionariam como representações sintéticas e simbólicas da realidade, de resto, procedimento comum à literatura de Machado de Assis. Eulálio, como se vê, não fala de apólogo no sentido comum do termo, como uma narrativa que envolveria, de modo geral, seres inanimados e contaria com uma moral explícita ou implícita, tal qual a fábula ou a parábola. Deste último tipo de apólogo, há um exemplo na própria obra de Machado de Assis, o conto "Um apólogo", do volume Várias histórias (1896).

19 PRADO, cit., p. 34. 
passatempo, em nome de certo pudor postiço, que o narrador deixa entrever. Depois das insistências dos convivas, Santos cede:

Quis resistir; não era bonito que no próprio dia em que o regímen caíra ou ia cair, entregasse o espírito a recreações de sociedade... Não pensou isto em voz alta nem baixa, mas consigo, e talvez leu no rosto da mulher. Acharia um pretexto para resistir, se buscasse algum, mas amigos e cartas não deixavam buscar nada. Santos acabou aceitando. Provavelmente era essa mesma a inclinação íntima. Muitas há que precisam ser atraídas cá fora como um favor ou concessão da pessoa. Enfim, o basto e a espadilha fizeram naquela noite o seu ofício, como as mariposas e os ratos, os ventos e as ondas, o lume das estrelas e o sono dos cidadãos. ${ }^{20}$

Note-se nesta passagem como o narrador se isenta de maiores comentários para definir os reais sentimentos de Santos, com o uso dos advérbios talvez e provavelmente. Essa é uma operação de que o narrador lança mão ao longo de todo o romance, sempre no sentido de não fixar as consciências dos personagens; algo que o faz, porém, como narradordemiurgo, quando lhe convém. Essa estratégia mantém o teor sibilino das sugestões, abrindo caminho para a frase que fecha o parágrafo, que tenderia ao simbólico: o ofício do voltarete e de todas as coisas se mantém, garantindo o tom de identidade entre o dia anterior e o atual, mesmo que a transição da ordem política tenha ocorrido. Assim, embora não possamos ter a clareza em identificar "o basto e espadilha" e o "sono dos cidadãos" a elementos diretamente ligados à questão política, é possível dizer que essas menções do narrador não constituem elementos acessórios, pairando no ar a mesma dúvida que o narrador se esforça em manter. Assim, indicariam os trunfos do voltarete - a espadilha, por exemplo, indicando a espada militar do golpe de Estado recém-perpetrado - os atores políticos do momento, e o "sono dos cidadãos" o parco impacto da mudança do regime? A dúvida paira, pois, seguindo a tenção do narrador: uma "atmosfera de dúvida e insegurança", como lembra Gledson. ${ }^{21}$

O narrador de Numa e a Ninfa, ao contrário, não deixa espaço para um desafio ao leitor, mas perfaz uma postura que se quer agressiva, de modo a

20 ASSIS, cit., p. 1034, grifo nosso.

21 GLEDSON, cit., p. 196. 
explicitar o juízo sobre os acontecimentos. Diferentemente do leitor "ruminante", que "deduz a verdade, que estava, ou parecia estar escondida", tal qual afirma o narrador de Esaú e Jacó, ${ }^{22}$ o narrador barretiano, quando interfere, se dirige pelo alto, em uma forma de controle da matéria narrada totalmente diversa. O domínio e o julgamento se constroem de modo a não deixar pontos dubitativos sobre o que se pretende ser a verdade da narrativa. Assim é caracterizado o ambiente político quando da ascensão do general Bentes:

Com os novos governantes, o pavor do começo transformou-se em falsa alegria de encomenda. [...] Um riso de prostituta em orgia sesquipedal. Houve a indústria de manifestações e Lucrécio aproveitou muito com ela, enquanto os serviços não eram encaminhados mais eficazmente. Havia necessidade, de fazer crer ao povo, que a opinião desejava ardentemente fazer a imissão do Messias nas rédeas do Estado, e o povo faz-se graças à necessidade, graças à ilusão do Estado e à simplicidade dos esmagados. ${ }^{23}$

$\mathrm{O}$ riso da prostituta em uma grande orgia, a invectiva à instrumentalização do Estado, a caracterização do povo como "esmagado" por sua simplicidade perfazem a nota crítica do romance, em tom de panfleto. Se Machado, mesmo em suas crônicas, abusa da dúvida e do desafio ao leitor, envolvendo-o em uma malha ao mesmo tempo incômoda e familiar, Lima desenha seu narrador como fora o escritor político da imprensa da segunda década do século XX, com opinião e posição meridianamente reconhecíveis e até agressivas. A "simplicidade dos esmagados", aqui, parece correlata ao cotidiano que segue incólume após a transição política, com o "sono dos cidadãos" citado em evasiva no romance machadiano. No entanto, um se impõe como verdade indubitável e desejada pelo narrador, enquanto outro demonstra a aversão a conclusões taxativas. Apesar disso, é impossível não vislumbrar nessas duas passagens a representação literária, em registros quase simetricamente opostos, de uma estrutura política que se dá à margem do conjunto da população, com uma dinâmica estatal na qual sucedem governos mas não a função de dominação das elites sobre a fraturada sociedade brasileira. Assim, embora as construções se mostrem efetivamente

22 ASSIS, cit., p. 1019.

23 BARRETO, Prosa seleta, p. 469. 
incompatíveis, o teor do diagnóstico permanece, um sob olhar dubitativo, outro guiado pela exasperação do narrador político.

No tocante aos personagens-delegados, ocorre algo correlato entre os dois romances. Em Esaú e Jacó, como já visto, há uma relação funcional entre o narrador e a personagem do Conselheiro Aires, para os quais são comuns as evasivas e a aversão a asserções sobre os demais personagens e acontecimentos. No capítulo "O salmão", sobre um almoço que Aires realiza para tentar apaziguar os ânimos dos gêmeos Pedro e Paulo, o caráter daquele vem à tona, mediado pelos acontecimentos e com o beneplácito do narrador, que completa a cena:

O almoço ia fazendo o seu ofício. Aires estudava os dous rapazes e suas opiniões. Talvez estas não passassem de uma erupção de pele da idade. E sorria, fazia-os comer e beber, chegou a falar de moças, mas aqui os rapazes, vexados e respeitosos, não acompanharam o ex-ministro. A política veio morrendo. Na verdade, Paulo ainda se declarou capaz de derribar a monarquia com dez homens, e Pedro de extirpar o gérmen republicano com um decreto. Mas o ex-ministro, sem mais decreto que uma caçarola, nem mais homens que o seu cozinheiro, envolveu os dous regímens no mesmo salmão delicioso. ${ }^{24}$

Da postura geral de Aires, a ironia e o sorriso conciliador perfazem sua marca. Diversamente das opiniões irreconciliáveis dos gêmeos - Paulo, republicano; Pedro, monarquista -, a resposta de Aires, em consonância com o narrador e em discurso indireto, é tratá-las como uma "erupção de pele": convicção e inflamação cutânea efêmeras, ambas adolescentes. O narrador, em consonância com seu personagem-delegado, marca o tom geral das divergências, no qual uma opinião vale pela outra: os dois regimes políticos podem muito bem partilhar da mesma mesa. A veleidade do narrador, que seleciona o aprofundamento das consciências de seus personagens num vai e vem segundo lhe apraz, parece, nesse sentido, comungar e espelhar as opiniões do - assim dito - escritor das memórias nas quais baseia sua narrativa. Um e outro colocam seguidamente em suspenso opiniões, asserções e juízos, em uma conciliação que parece enfatizar a mútua reversibilidade das opiniões divergentes, com o foco último na política. Se, durante o Império, não há nada mais parecido com um saquarema -

24 ASSIS, cit., p. 1002. 
conservador - que um luzia - liberal -, ${ }^{25}$ entre republicanos e monarquistas o jogo de identidade parecia permanecer:

Convence-te de uma ideia, e morrerás por ela, escreveu Aires por esse tempo no Memorial, e acrescentou: "nem é outra a grandeza dos sacrifícios, mas se a verdade acerta com a convicção, então nasce o sublime, e atrás dele o útil...". Não acabou ou não explicou esta frase. ${ }^{26}$

Narrador veleitário e personagem-delegado, aqui, juntam-se no misto de ironia e cinismo: convicções e ideias valem pelo útil, pelo seu valor de face; nesse ponto, são idênticas e reversíveis. O narrador se ausenta da explicação que Aires não concede, dando a deixa para o leitor permanecer em dúvida sobre o que possam significar, embora com certa malícia mal disfarçada. Aires representa, assim, no jogo de espelhos do romance, uma personagem modelar para que a avaliação sobre a política possa aflorar, com a própria dúvida incentivando o ceticismo sobre as lealdades e as convicções. ${ }^{27}$ Daí a irônica lembrança do leitor "ruminante", que pode tirar suas conclusões, "se gosta de concluir". ${ }^{28}$

Em Numa e a Ninfa, Benevenuto e Bogóloff correspondem a esse duplo do narrador, como personagens-delegados do romance ou mesmo uma espécie de raissonneurs à moda teatral. Benevenuto é primo e amante de Edgarda, redator secreto dos discursos de Numa e conselheiro político que orienta a mulher em como guiar a carreira política do marido. Trata-se de uma espécie de boêmio cético em relação à política do país, cuja indignação é, no entanto, acalmada pelos amores da prima e por um senso de incapacidade para a atuação prática que o coloca à margem dos acontecimentos, posição própria para que possa influir, através da amante, na carreira de Numa, ajudando-o a galgar postos dentro do partido e do

25 Idem, p. 1005.

26 Idem, p. 1056. Grifo nosso.

27 Cabe lembrar, em reforço à metáfora do espelho e das identidades mutuamente reversíveis politicamente, no nosso caso -, que o romance se compõe de 121 capítulos. Na sua metade, capítulo LX, figura o dia da proclamação da República, "Manhã de 15". Assim, o romance se divide quase perfeitamente entre os capítulos ambientados no período monárquico, e os já posteriores à implantação da República. O número que escapa à divisão perfeita - 121, e não 120 capítulos - parece ser mais uma artimanha que propõe evitar juízos definitivos.

28 ASSIS, cit., p. 1019. 
governo. No entanto, vez ou outra, quando sua consciência é exposta pelo narrador - como na próxima passagem, que segue à repressão da população pelo governo do general Bentes -, há certa identidade entre seu discurso e o tom de libelo disseminado na narrativa:

Benevenuto, que sempre fora totalmente infenso aos conluios políticos, que mesmo duvidava da pátria, sentia dentro de si energias agora sopitadas. Aquele espetáculo de subserviência geral, aquele amordaçamento da opinião, aquela série de delitos de toda a natureza, reagiram sobre ele e tiraram-no do seu quietismo. [...]

Os últimos sucessos escandalizaram-no; ele tinha como que remorso deles, vergonha, sem ter tomado parte direta ou indiretamente neles. Acusava o seu silêncio, julgava-se covarde e, com a sua covardia, responsável por tudo o que de sangue, de opressão, de força bruta e selvagem se anunciava. ${ }^{29}$

Benevenuto, assim, é utilizado pelo narrador para reforçar sua acusação ao processo político do momento. Diferentemente de Aires, resguardado em sua posição que paira acima do problema político, Benevenuto, quando acercado pela voz narrativa, expõe de maneira clara tanto sua revolta quanto sua impotência. Não é demais lembrar que ele irá, novamente, ao fim da narrativa, auxiliar a prima na redação de mais um discurso do marido; flagrados em carícias por Numa, o deputado se lembra de que um rompimento seria desastroso para sua carreira: "Que descoberta? Que devia fazer? A carreira... o prestígio... senador... presidente... Ora bolas!". ${ }^{30}$

Bogóloff mantém trajetória parecida à de Benevenuto, no tocante a seu papel dentro do romance. Emigrado russo, Bogóloff tentara sem sucesso a produção agrícola em uma colônia. Mudando para o Rio de Janeiro, estabelece contato com Lucrécio Barba-de-Bode, capoeira e capanga político dos grupos próximos ao poder. Quando Bentes alça à presidência, Lucrécio intervém pelo russo, e consegue que ele fosse nomeado como diretor da Pecuária Nacional, convencendo o ministro recém-empossado com ideias estapafúrdias como a criação de "porcos do tamanho de bois e bois do tamanho de porcos", formando assim a "Estação Experimental de Reversão

29 BARRETO, cit., p. 510.

30 Idem, p. 554. 
Animal e Quadruplicação dos Bois". ${ }^{31}$ A nota picaresca é patente, perfazendo uma trajetória que vai da indignação pessoal contra as condições do povo brasileiro a um oportunismo sem medida - a situação de Benevenuto levada ao paroxismo, digamos. O narrador assim descreve o caráter de Bogóloff, depois de liberto de uma prisão russa:

Rolou de cidade em cidade, depois de ter perdido o pai; por fim veio para o Brasil para sossegar e morrer.

Não tinha mais escrúpulos; e se não cobria a humanidade com desprezo, desprezava-se a si mesmo, não se detendo diante empecilho moral, senão daquele que fosse castigado pelo Código.

A terra era boa e chã; e ele não se incomodava em saber se era bem governada ou mal. Ia vivendo com a sua liberdade interior, perfeita e completa. ${ }^{32}$

A perda das ilusões de Bogóloff convive com um oportunismo que marca sua única possibilidade de viver decentemente no país. Como o "homem que sabia javanês" 33 do conto de Lima Barreto, como Lucrécio e como o próprio país que adota, limita-se a viver de "expedientes". ${ }^{34} \mathrm{~A}$ situação da política brasileira, mesmo que ele a perceba como autoritária e alheia às necessidades do povo, pouco importa, o que equaliza o diagnóstico do narrador à peripécia farsesca de seu personagem. Ainda assim, a desfaçatez da política brasileira o surpreende. Quando um interlocutor de Bogóloff compara um político ao imperador romano Marco Aurélio por não ter recebido propina de fornecedores no período em estava ao governo, Bogóloff pensa, pela voz do narrador: "Pois um homem é Marco Aurélio só porque não furtou dez tostões?". ${ }^{35}$ A questão dos personagens-delegados em Lima Barreto, nesse sentido, tende a fazer coro e a carregar nas tintas das críticas que o narrador já delineara, um papel que se afasta do teor dubitativo compartilhado pelo narrador machadiano e pelo conselheiro Aires.

31 Idem, p. 495, 508.

32 Idem, p. 509.

33 Idem, p. 1129-1135.

34 Idem, p. 456.

35 Idem, p. 540. 


\section{A "flor eterna": o concerto da política no país dos expedientes}

Com base na relação entre narradores e seus porta-vozes, pode-se já perceber qual a configuração da política brasileira que está na pauta de Esaú e Jacó e Numa e a Ninfa. Enquanto o narrador machadiano, apoiado por Aires, sugere em irônica cautela uma identidade formal entre os regimes, denotando a vacuidade das filiações e a distância existente entre ideias e fins, o barretiano joga seus personagens em um palco estritamente controlado por sua visão militante, no qual cada ente desempenha seu papel na trama farsesca. O alvo, como se pôde notar, está voltado para as elites dirigentes brasileiras, cuja prática política se dá dissociada da sociedade civil, em uma estrutura na qual lealdades políticas e programas partidários, bem como a própria violência, no caso de Numa e a Ninfa, são instrumentos como quaisquer outros para a reprodução da estrutura do poder. A incontornável sensação de déjà-vu, assim, atravessa ambas as obras.

Nesse sentido, a contenda entre os gêmeos Pedro e Paulo que perpassa toda a narrativa, bem como a indecisão de Flora, que oscila entre ambos, perfazem a relação simbólica que já delineamos nas próprias idas e vindas do narrador e de seu personagem-delegado. Depois de duas tentativas de reconciliação entre os gêmeos - afora as de Aires -, imediatamente após a morte de Flora e da mãe Natividade, ambos, já eleitos deputados, decerto por partidos opostos, têm seus comportamentos políticos comentados a um interlocutor por Aires, que os conhecera desde o útero, quando já teriam dissentido, como os irmãos bíblicos Esaú e Jacó: "eram os mesmos. [Aires] preferiu aceitar a hipótese, para evitar debate, e saiu apalpando a botoeira, onde viçava a mesma flor eterna". ${ }^{36}$ Trata-se do fecho do romance, e o mesmo, utilizado por duas vezes, lança a dúvida - "para evitar debate" sobre se se trata da manutenção da personalidade de cada um dos gêmeos ou, ao contrário, da impressão que levara Flora à morte: a de uma "fusão"37 entre eles, o que reforça a avaliação ironicamente sugerida sobre a política pelo narrador e seu porta-voz - a "flor eterna" e a constante reposição dos mesmos problemas, a despeito da convicção política e do regime adotado. Trata-se, pois, da mesma sugestão do conhecido apólogo - como o chama

36 ASSIS, cit., p. 1093.

37 Idem, p. 1048-1049. 
Alexandre Eulálio - ${ }^{38}$ da tabuleta da confeitaria do Custódio. Confeitaria do Império ou da República, o valor está na sua mútua reversibilidade e em seu valor de face - no caso, de fachada. ${ }^{39}$

A dimensão simbólica ou alegórica em Esaú e Jacó, no entanto, não se restringe aos personagens principais. Quando opta por encenar diretamente a comédia política, o narrador não evita a caricaturização, o que visivelmente ocorre em dois personagens: o casal d. Cláudia e Batista. Batista - para quem "a política era menos uma opinião que uma sarna" -, político conservador, pouco hesita em trocar de partido frente aos rogos da mulher, que o aconselha a se aproximar dos liberais, os quais ocupavam o gabinete ministerial do período: "não é preciso ter as mesmas ideias para dançar a mesma quadrilha". ${ }^{40}$ Político nato mas pouco desenvolto nas encenações palacianas, a relação de Batista com d. Cláudia em muito lembra a correlata entre Numa e Edgarda: duas mulheres de temperamento resoluto frente à índole passiva dos maridos. ${ }^{41}$ Batista torna-se liberal como seria republicano, tal qual Numa se deixa guiar pelos sucessivos "vencedores" do momento. Nos dois casos, portanto, quando a caracterização da comédia política salta à vista, a caricatura parece ser o meio empregado. No entanto, se onipresente no libelo de Lima Barreto, no romance de Machado de Assis ela se apresenta como um processo composicional a mais, fazendo constelação com outros na sugestão crítica do processo político brasileiro. Ainda, cabe questionar se mesmo os personagens de Lima Barreto, caricaturas de um roman à clef, não tendem a se tornar uma espécie de alegoria, dado o distanciamento temporal do alvo sobre a política a que fazia referência. Assim, Numa, Cogominho, Benevenuto, Bentes e outros se tornariam uma espécie de figuras típicas de uma estrutura política que pouco parece variar em suas configurações essenciais, indicando a série de arranjos já provados durante o Império e que fariam carreira também durante o período republicano.

À parte, pois, os diferentes processos adotados pelos romancistas, a comparação entre Esaú e Jacó e Numa e a Ninfa dá margem a pensar sobre uma representação da política brasileira que beira uma compreensão estrutural de seu processo, no qual certas práticas e problemas parecem apenas merecer atualizações, mas não questionamentos de fundo. A ausência

38 EULÁLIO, cit., p. 121.

39 Idem, p. 1027-1030.

40 Idem, p. 1004.

41 BROCA, Machado de Assis e a politica e outros estudos, p. 87. 
de cidadania e de participação popular, o patrimonialismo, a ausência de densidade de programas, as filiações escusas calcadas no personalismo, a tautológica reprodução das estruturas do poder são marcas que perfariam inclusive as avaliações presentes em parte do pensamento social brasileiro, indicando uma permanência incômoda cuja resolução provavelmente ainda esteja no horizonte. Em suas crônicas, romances e contos, Lima Barreto e Machado de Assis, a partir de suas especificidades, não descuraram destas questões, o que talvez possa explicar o fato de que duas estruturas romanescas diversas tenham por alvo e diagnóstico o mesmo problema fulcral. Seja na "Sereníssima República" ou nos "Estados Unidos da Bruzundanga", a literatura pôde lançar questões que a história permanece por responder.

\section{Referências}

ASSIS, Machado de. Obra completa. Rio de Janeiro: Nova Aguilar, 1986.

BARBOSA, Francisco de Assis. A vida de Lima Barreto. 6. ed. Rio de Janeiro: José Olympio; Instituto Nacional do Livro, 1981.

BARRETO, Lima. Correspondência. São Paulo: Brasiliense, 1956. vol. 1. (Obras completas; 17).

. Prosa seleta. Rio de Janeiro: Nova Aguilar, 2001.

. Contos completos de Lima Barreto. São Paulo: Companhia das Letras, 2010.

BEIGUELMAN, Paula. Por que Lima Barreto. São Paulo: Brasiliense, 1981.

BROCA, Brito. Machado de Assis e a política e outros estudos. Rio de Janeiro: Simões, 1957.

CANDIDO, Antonio. Os olhos, a barca e o espelho. In: A educação pela noite.

5. ed. Rio de Janeiro: Ouro sobre azul, 2006, p. 47-60.

EULÁLIO, Alexandre. Esaú e Jacó: narrador e personagens diante do espelho. In:

Tempo reencontrado: ensaios sobre arte e literatura. São Paulo: Instituto Moreira Salles; Editora 34, 2012, p. 139-166.

GLEDSON, John. Introdução. In: ASSIS, Machado de. A Semana: crônicas (18921893). São Paulo: Hucitec, 1996, p. 11-34.

. Machado de Assis: Fiç̧ão e História. 2. ed. São Paulo: Paz e Terra, 2003.

GUIMARÃES, Hélio de Seixas. Esaú e Jacó e o leitor como duplo. In: Os leitores de Machado de Assis: o romance machadiano e o público de literatura no século 19. São Paulo: Nankin; Edusp, 2004, p. 239-266. 
HOLANDA, Sérgio Buarque de. Clara dos Anjos. In: Livro dos prefácios. São Paulo: Companhia das Letras, 1996, p. 384-394.

PEREIRA, Astrojildo. A máscara do Dr. Bogóloff. In: BARRETO, Lima. Prosa seleta. Rio de Janeiro: Nova Aguilar, 2001, p. 52-58.

PRADO, Antonio Arnoni. Lima Barreto: o crítico e a crise. Rio de Janeiro: Cátedra; Brasília: INL, 1976.

JÚLIO CEZAR BASTONI da Silva é licenciado em Letras pela Universidade Federal de São Carlos (UFSCar) e recém-doutor em Estudos Literários pela Universidade Estadual Paulista 'Júlio de Mesquita Filho', campus Araraquara (UNESP-FCLAr). Pesquisa majoritariamente sobre a relação entre a literatura brasileira e a construção da nacionalidade, com foco na relação entre ficção e o pensamento social e político brasileiro. Atualmente desenvolve projeto de pósdoutorado sobre a obra do contista paulistano João Antônio. E-mail: <juliobastoni@yahoo.com.br>

Recebido: 15.09 .14

Aprovado: 30.10 .14 